\title{
Synthesis, Characterization, and Antibacterial Activity of Biosynthesized Gold Nanoparticles
}

\author{
Emilin Renitta R ${ }^{1}$, Smitha I ${ }^{2}$, Chamarthy Sai Sahithya ${ }^{3}$, Antony V Samrot ${ }^{4 * \mathbb{D}}$, Abirami $\mathbf{S}^{5}$, Dhiva $\mathbf{S}^{6}$, \\ Daniel Alex Anand ${ }^{7}$

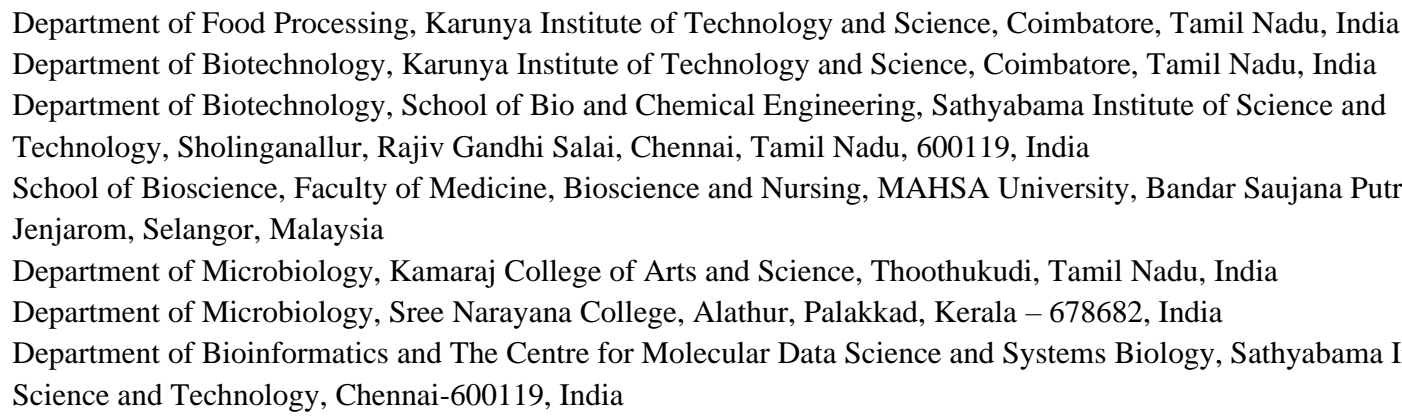

Received: 19.08.2020; Revised: 11.09.2020; Accepted: 12.09.2020; Published: 15.09.2020

\begin{abstract}
In this study, Acalypha indica was utilized to green synthesize gold nanoparticles. The characteristics of the synthesized nanoparticles were observed through UV-Vis, FTIR, TEM, particle size analyzer, and XRD. Furthermore, the nanoparticles were investigated for antibacterial properties. The particle size of gold nanoparticle was around $50-100 \mathrm{~nm}$, and the antibacterial property of the nanoparticle was assessed using agar well diffusion, swarming motility, MIC, and protein leakage assay. The gold nanoparticles were observed to be active against $E$.coli alone with MIC at $160 \mu \mathrm{g}$, and it was observed to inhibit its swarming motility and to make the cell leak out proteins.
\end{abstract}

Keywords: Acalypha indica; gold nanoparticles; antibacterial activity; protein leakage assay.

(C) 2020 by the authors. This article is an open-access article distributed under the terms and conditions of the Creative Commons Attribution (CC BY) license (https://creativecommons.org/licenses/by/4.0/).

\section{Introduction}

Nanobiotechnology can be defined as the manipulation of biological living systems at the molecular size between 1 and $100 \mathrm{~nm}$. These nanoparticles have been well exploited in the field of biomedical engineering, biotechnology, pharmaceutical industries, environment, etc. [1-3]. Metal-based nanoparticles are used more these days as they possess various bioactivities $[4,5]$. Nanomaterials possess unique properties that have drawn major attention in terms of pharmaceutical applications [6]. However, there are certain disadvantages involved in physiochemical methods that include the usage of noxious chemicals, time consumption, stability, production of hazardous products, and large-sized and aggregated products[7]. Hence, these impediments have called for the advancement of an environmental-friendly, less consumption of energy and green production approach using biological systems (microbes, algae, plants, and plant-derived products) [8, 9]. This environmental and green synthesis approach does not involve the usage of hazardous chemicals as opposed to chemical procedures that make use of hazardous reagents in its practice [10]. 
Amongst all, the stability of gold nanoparticles is high in comparison with the other metal nanoparticles, which increased their application in photo thermolysis, drug delivery, cancer diagnosis, and treatment [11, 12]. Moreover, their biocompatibility and a strong interface with soft bases such as thiols have increased its use in various bioactivity studies [13]. On most occasions, these gold nanoparticles are produced by the chemical method that makes use of aggressive chemicals like sodium borohydride, hydrazinium hydroxide, cetyltrimethylammonium bromide, but despite their advantage, they possess toxicity [14]. A remarkable emanating recent approach of green synthesis of biogenic nanoparticles from biological sources played a role in cancer due to their attributes dealt with cost efficiency and less toxic in nature [15]. Barabadi et al. [16] stated that the biometal nanoparticles synthesized by Penicillium sp had a pharmaceutical potential and were investigated for antimicrobial efficacy, which explored the applications of NPs.

The gold nanoparticles produced utilizing various bacteria, fungi [17], and plant extracts that make them useful in most biomedical fields [18]. Khatua et al. [19] stated that Pongamia. pinnata leaf extract was a potential reducing and stabilizing agent in the formation of colloidal AuNPs which fight against fungal species. There was a higher scolicidal activity observed in nanoparticles that were obtained from the solvent aerial extract of Penicillium aculeatum that was evaluated against the protoscolices of CHD in-vitro [20]. Bio-production of gold nanoparticles from Terminalia catappa [21], tea [22] lemongrass [23] has been investigated as well. Lee et al. [24] described that numerous surface functionalities of AuNPs permit them to be more vigorous when joined with various biological aggregations or mitigation for improved applications. Keijok et al. [25] demonstrated that the Coffea arabica plant extract proved as a reducing agent, stabilizer, and functionalizer for the synthesized gold nanoparticles. A research study on Salix alba leaf extract was a good bio-reductant for gold nanoparticles synthesis and had prospective for various pharmaceutical applications[26]. Besides, another research revealed that the gold nanoparticles (AuNPs) produced from Scutellaria barbata have promising anticancer activity against pancreatic cancer cell lines (PANC-1)[27]. Wongyai et al. [28] observed that the gold nanoparticles synthesized from Cryptolepis buchanani was profoundly crystalline and monodispersed spherical AuNPs.

Furthermore, green nanoparticles may serve as a novel anticancer agent that could target cancerous cells [29]. According to Saravanan et al. [30], nanomedicine developed could be used for HIV treatment by interfering with HIV life cycle. Recently, BMNPs have been appraised as a possible approach to provide resistance against vectors of malaria that could lead to treating malaria disease [31]. Even though metal nanoparticles provide more promising applications, several causes for concern have been appraised in regards to the safety and impact of the nanomaterials for human use. This review had also mentioned the risk of carcinogenesis that may occur as a result of exposure to nanomaterials [32]. Honary et al. [33] recommended that silver nanoparticles synthesized by $P$. citrinum could be suitable in emerging a biological process. Further research carried out by Barabadi et al. [34] showed the development of a mycosynthesized silver nanoparticle using P.citrinum by response surface methodology. Another research study reported by a team of researchers involved the biological synthesis of extracellular iron oxide nanoparticles using P.waksmanni isolated from soil [35].

Acalypha indica, which belongs to the family of Euphorbiaceae, is commonly seen in tropical Africa, India, Sri Lanka, etc. This plant has been said to exhibit antimicrobial action against bacteria [36]. Very few studies have been reported in utilizing Acalypha indica for gold synthesis, and therefore, using this plant might give versatile gold nanoparticles. Hence, in this 
current study, leaves of Acalypha indica was utilized to produce gold nanoparticles, followed by characterization using UV-Vis spectroscopy, FTIR, XRD, Particle size analyzer, TEM, and EDX. Subsequently, synthesized gold nanoparticles were studied for its antimicrobial property against Escherichia coli, Shigella dysenteriae, Salmonella typhi, Bacillus subtilis, and Staphylococcus aureus.

\section{Materials and Methods}

\subsection{Synthesis of gold nanoparticles.}

2.1.1. Collection and identification of plant material.

The plant material was obtained from Karunyanagar, Coimbatore, Tamil Nadu, India. The plant material was recognized as Acalypha indica by Dr. A. Annamalai, Associate Professor, Department of Biotechnology, Karunya Institute of Technology and Sciences.

\subsubsection{Preparation of plant extract.}

Plant leaves were collected, cleaned first in tap water, and then later by distilled water. Leaves were finely chopped and weighed $10 \mathrm{~g}$ of leaves was heated with $100 \mathrm{~mL}$ MilliQ water at $55{ }^{0} \mathrm{C}$ for $1 \mathrm{~h}$. The obtained mixture was then filtered using Whatman filter.

\subsubsection{Synthesis of gold nanoparticles.}

$75 \mathrm{~mL}(15 \%)$ of plant extract was made into $500 \mathrm{~mL}$ by adding MilliQ water and added with $0.19 \mathrm{~g}$ chloroauric acid. The solution was kept undisturbed at room temperature in dark conditions. It was noted for change of color after $20 \mathrm{~h}$. The formation of gold nanoparticles was observed by subjecting the solution to UV-vis spectra at $20^{\text {th }} \mathrm{h}$ and $40^{\text {th }} \mathrm{h}$.

\subsection{Characterization of gold nanoparticles.}

FTIR analysis was carried out for the particle as well as the extract to find the role of phytoconstituents in gold nanoparticle formation. UV-Vis and Particle size analyses were done using UV-2910 Hitachi spectrophotometer and particle size analyzer (Malvern Zetasizer Nanosizer), respectively. The particles were also subjected to TEM (Transmission electron microscopy) and XRD (X-ray diffraction) studies.

\subsection{Evaluation of antimicrobial activity.}

The obtained gold nanoparticles were evaluated for antibacterial property against Escherichia coli, Shigella dysenteriae, Salmonella typhi, Bacillus subtilis, and Staphylococcus aureus by agar well diffusion method [37]. MIC and Swarming motility against the sensitive organisms was done using the method of Pal et al. [38] and Samrot et al. [4], respectively. Protein Leakage $[4,39,40]$ was also performed for the gold nanoparticles against the bacteria, which showed sensitivity to the particle.

\section{Results and Discussion}

Plant extracts possess a high amount of carbohydrates and protein biomolecules that exhibit reducing agent properties, which prompt the development of metal nanoparticles [41]. 
Furthermore, the proteins associated with a functional cluster of amino groups $\left(-\mathrm{NH}_{2}\right)$ are present in plant extracts and can take part as a vital role in the reduction of metal ions [42]. The presence of active groups (such as $-\mathrm{C}-\mathrm{O}-\mathrm{C}-,-\mathrm{C}-\mathrm{O}-,-\mathrm{C}=\mathrm{C}-$, and $-\mathrm{C}=\mathrm{O}-$ ) in phytochemical compounds such as flavones, alkaloids, phenols, and anthracenes can assist in the promotion of metal nanoparticles. This method is considered as one of the simplest approaches as they do not call for an aseptic environment. The reaction (economic) can be easily initiated through interaction with the starting material that does not require high temperature or pressuremoreover, Acalypha indica act as a novel source of bio-reductants. The formation of gold nanoparticles produced using Acalypha indica was evidenced by the color change to purplered. Equivalent results were observed by Krishnaraj et al. [43] where he used Acalypha indica to produce gold nanoparticles that were characterized by various methods, and their results are as follows.

\subsection{FT-IR analysis.}

FT-IR results of the leaf extract revealed prominent absorption bands at 3726.47, $3522.02,2927.94,2357.01,2312.65,1681.93,1519.91 \mathrm{~cm}^{-1}$, and various cluster peaks ranging between 1500 and $1000 \mathrm{~cm}^{-1}$ were also observed. The peaks at 2927.94, 2357.01, 2312.65 $\mathrm{cm}^{-}$ ${ }^{1}$ corresponded to the phosphine functional group (P-H stretch) and alkanes functional group (C-H stretch). The cluster of peaks from 1458.18 to 1033.85 corresponds to the presence of various alkenes (C-H plane bend) (Figure 1a). Gold nanoparticle showed prominent absorption bands at 3359.56, 3730.33, 2353.16, 2312.65, 1788.01, 1739.79, 1516.05 $\mathrm{cm}^{-1}$ (Figure 1b). There were shifts in wavenumbers from the extract to gold nanoparticles, which confirmed the role of extract in the formation of gold nanoparticles [44]. This study is in accordance with Barbadi et al. [45], who reported that the Fourier transform infrared (FT-IR) study of AuNPs synthesized using Penicillium aculeatum revealed the existence of possible functional groups that accounts for bioreduction and capping.

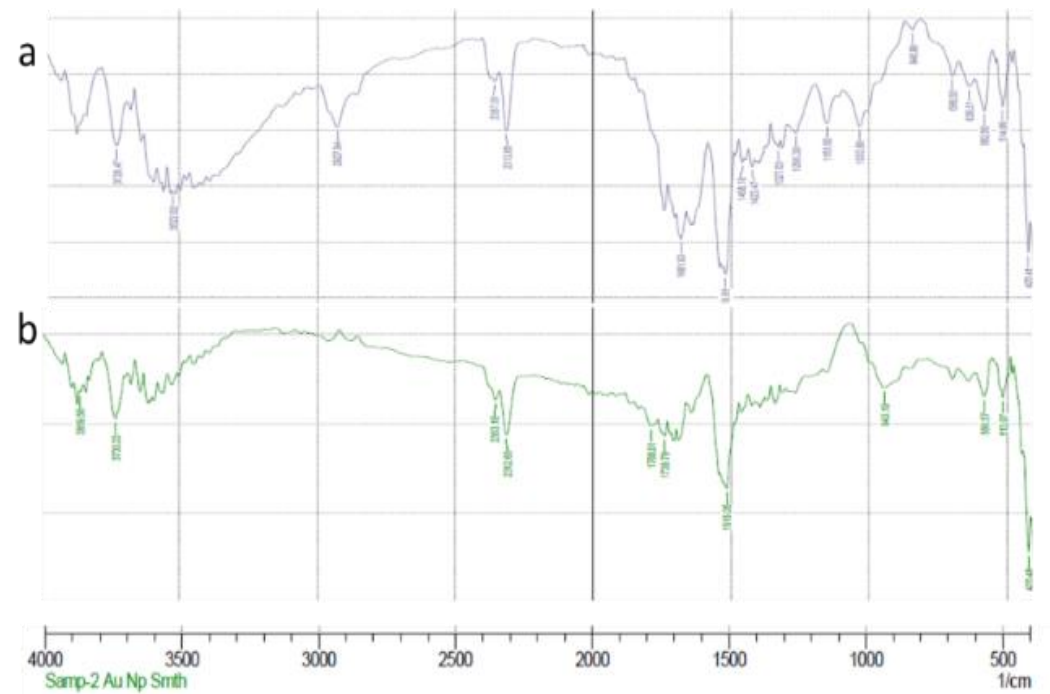

Figure 1. FTIR spectra of (a) Acalypha indica leaf crude extract; (b) gold nanoparticles synthesized using Acalypha indica extract.

\subsection{UV-Vis analysis of gold nanoparticles.}

Figure 4 displays the UV-visible absorption spectra recorded. A strong peak was observed at $542.5 \mathrm{~nm}$ in particles subjected for reduction for $40 \mathrm{~h}$. Ruby red-colored gold 
nanoparticles were reported to give absorbance maximum between 530 and $550 \mathrm{~nm}[46,47]$. There was a presence of broadness of peak (Figure2), and normally a narrow peak with a decreased bandwidth stands for bigger sized particles [48].

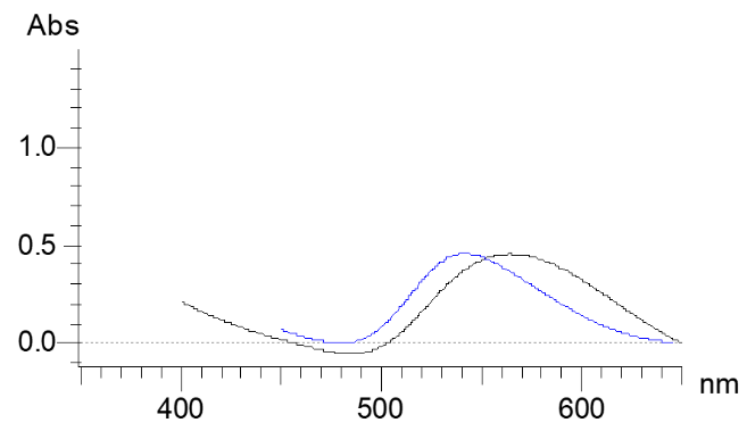

Figure 2. UV-Vis spectrum of gold nanoparticles synthesized using Acalypha indica; Black line - absorbance was taken at $20^{\text {th }} \mathrm{h}$, blue line absorbance taken at $40^{\text {th }}$ hour.

\subsection{Particle size analysis.}

Particle size analysis revealed the size of the particle distribution to be around $100 \mathrm{~nm}$ (Figure 3). This might be due to the accumulation of gold nanoparticles for a prolonged period of time. The particle size analysis of GNPs synthesized by Penicillium crustosum revealed the presence of spherical shaped particles with a mean average size under $100 \mathrm{~nm}$ that correlates with our results [49].

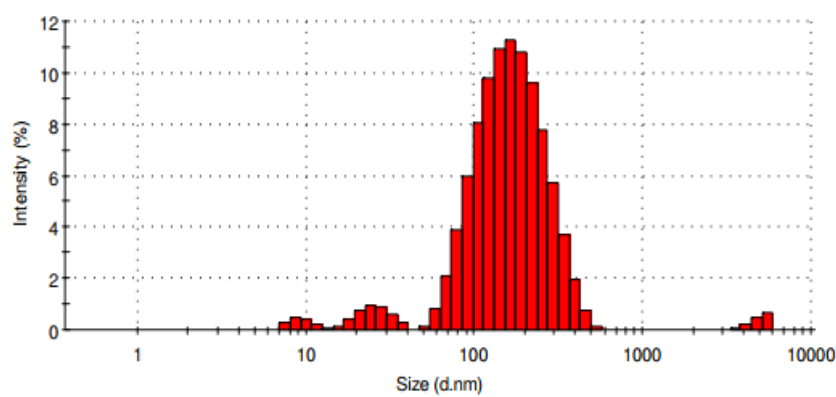

Figure 3. particle size analysis of gold nanoparticles.

\subsection{TEM analysis.}

Au NP cellular distribution and impacts were revealed using transmission microscopy, where the size was observed to be around $50 \mathrm{~nm}$ (Figure 4). Krishnaraj et al. [43] also reported the size of the gold nanoparticle to be around $30 \mathrm{~nm}$ that was obtained using the extract of Acalypha indica.

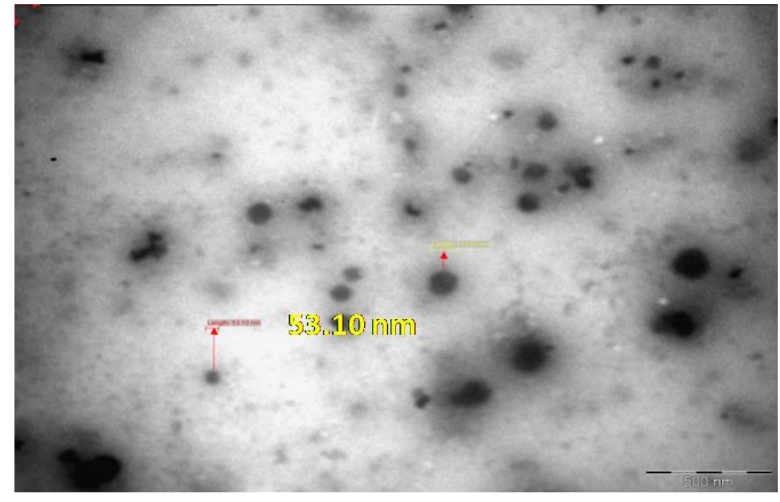

Figure 4. TEM images of gold nanoparticles synthesized using Acalypha indica leaf extract. 


\subsection{EDX analysis.}

EDX analysis showed predominant peaks for gold (Figure 5), and the presence of other elements might be due to the addition of chemical/salt present in water. This is in accordance with Khatua et al. [50], who reported similar results that displayed strong signals in favor of Au, confirming the formation of AuNPs using P. pinnata leaves.

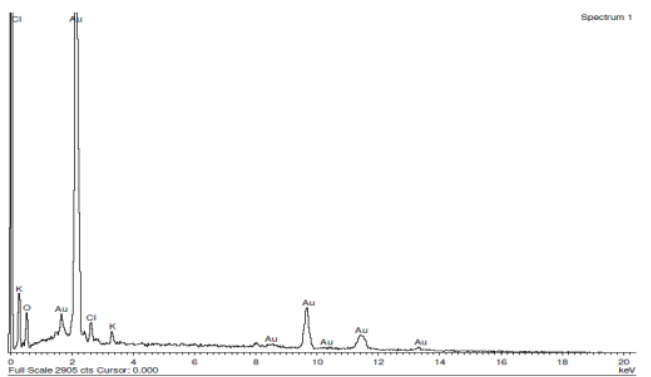

Figure 5. EDX pattern of Au NPs synthesized by Acalypha indica leaf extract.

3.6. X-Ray diffraction (XRD) analysis.

XRD analysis was found with four sharp peaks (Figure 6) in the XRD pattern at 2 theta values 38.4788 (111), 65.0189 (200), 44.6277 (220), and 77.8432 (311), which is on par with JCPDS card no 65- 2870 and belong to be cubic face-centered structure [5, 50]. Krishnaraj et al. [43] could also produce face-centered structured gold nanoparticle using the extract of Acalypha indica.

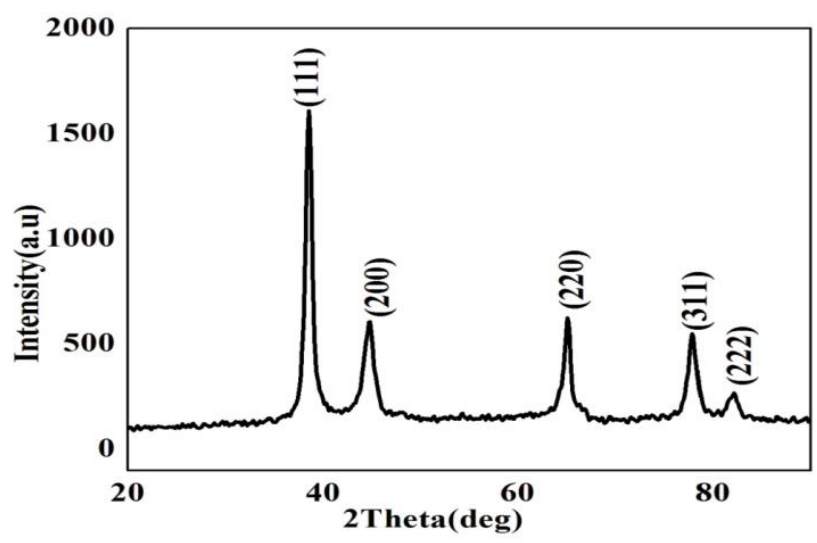

Figure 6. XRD pattern of gold nanoparticles synthesized using Acalypha indica leaf extract.

\subsection{Antimicrobial activity.}

The cell walls of both Gram-positive and Gram-negative bacteria consist of an anionic cell surface [51]. Due to the electrostatic interaction, the cationic NPs are drawn towards the surface of the opposite charged bacterial cell walls, and hence, the cationic metal nanoparticles institute a solid bond with the membranes that result in the disturbance of cell wall and increases permeability. Subsequently, the nanoparticles are capable of releasing metal ions from the extracellular matrix and thus, penetrating the cell and causing interference to the biological processes [52].

In the current study, the zone of inhibition was observed against E.coli alone (Table 1) at $160 \mu \mathrm{g}$ concentration, and minimal inhibitory concentration (MIC) was at $160 \mu \mathrm{g}$ (Table 2). 
It was even inhibiting the E.coli movement, which was evidenced by swarming motility (result not shown here).

Table 1. Antibacterial activity test against various microorganisms.

\begin{tabular}{l|c|c|c|c}
\hline \multirow{2}{*}{ Organism } & \multicolumn{4}{|c}{ Zone of inhibition $(\mathbf{m m})$} \\
\cline { 2 - 5 } & $\mathbf{4 0} \boldsymbol{\mu g}$ & $\mathbf{8 0} \boldsymbol{\mu g}$ & $\mathbf{1 2 0} \mathbf{~ g}$ & $\mathbf{1 6 0} \boldsymbol{\mu g}$ \\
\hline Escherichia coli & - & - & - & $2 \mathrm{~mm}$ \\
\hline Salmonella typhii & - & - & - & - \\
\hline Shigella dysenteriae & - & - & - & - \\
\hline Bacillus subtilis & - & - & - & - \\
\hline Staphylococcus aureus & - & - & - & - \\
\hline
\end{tabular}

Table 2. Determination of MIC.

\begin{tabular}{l|c|c|c|c|c}
\hline Organism & $\mathbf{4 0} \boldsymbol{\mu g}$ & $\mathbf{8 0} \boldsymbol{\mu g}$ & $\mathbf{1 2 0} \boldsymbol{\mu g}$ & $\mathbf{1 6 0} \boldsymbol{\mu g}$ & $\mathbf{2 0 0} \boldsymbol{\mu g}$ \\
\hline Escherichia coli & + & + & + & - & - \\
\hline
\end{tabular}

+ - presence of growth, - - no growth

Paul et al. [53] reported Parkiarox burghii mediated synthesized gold nanoparticles to have high antibacterial property against gram-positive bacteria compared to gram-negative bacteria. The organism was leaking out more protein when treated with gold nanoparticles (Figure 7). Metal nanoparticles have the ability to break the outer cell wall and leak out the cellular materials $[54,55]$. Thus there was an increase in the absorbance. The understanding of the biomedical advantage of biogenic metal nanoparticles (MNPs) is significant in order to be familiar with the hazards associated with the use of biogenic MNPs [56].

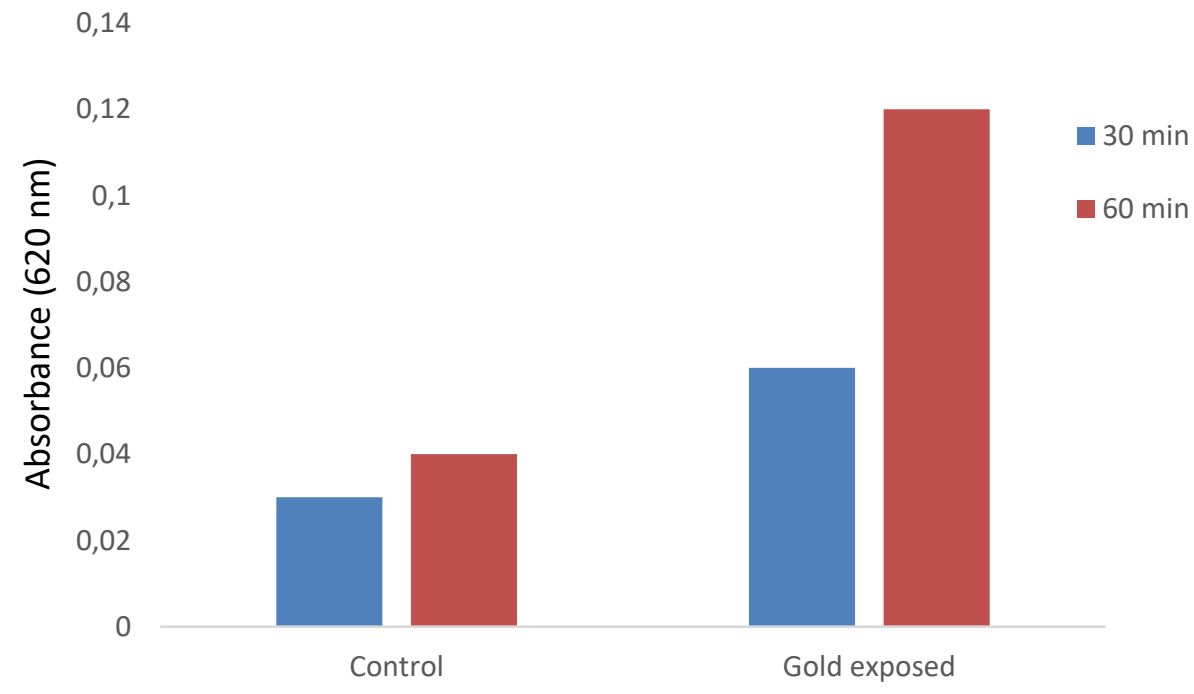

Figure 7. Protein leakage assay of gold nanoparticles.

\section{Conclusions}

The current study revealed that the gold nanoparticles synthesized from Acalypha indica had shown inhibitory against Escherichia coli. Therefore, gold nanoparticles were subjected to MIC and protein leakage assay to determine the antibacterial activity. The gold nanoparticles had MIC at $160 \mu \mathrm{g}$, and the particles were making the cells to leak out protein at $160 \mu \mathrm{g}$. Moreover, the characteristics of green synthesized gold nanoparticles were studied by SEM, XRD, FTIR. The observed size of the particle was around $50-100 \mathrm{~nm}$. The FTIR results exhibited the functional groups found in AuNPs. Hence the current study indicated that the gold nanoparticles synthesized could be considered as a potential bactericidal agent to treat 
pathogens. Nevertheless, supplement studies are statutory to understand the effectiveness of AuNPs in the animal model.

\section{Funding}

No fund was received for performing this work.

\section{Acknowledgments}

This paper has no acknowledgment.

\section{Conflicts of Interest}

None of the authors of this paper have any conflict of interest.

\section{References}

1. Poliakoff, M.; Anastas, P. A principled stance. Nature 2001, 413, 257-257, https://doi.org/10.1038/35095133.

2. Justin, C.; Samrot, A.V.; Sruthi, P.D.; Sahithya, C.S.; Bhavya, K.S.; Saipriya, C. Preparation, characterization and utilization of coreshell super paramagnetic iron oxide nanoparticles for curcumin delivery. PLos One 2018, 13, https://doi.org/10.1371/journal.pone.0200440.

3. Samrot, A.V.; Sahithya, C.S.; Selvarani, J.; Pachiyappan, S. Surface-engineered super-paramagnetic iron oxide nanoparticles for chromium removal. Int $J$ Nanomedicine 2019, 14, https://doi.org/10.2147/IJN.S214236.

4. Samrot, A.V.; Raji, P.; Selvarani, A.J.; Nishanthini, P. Antibacterial activity of some edible fruits and its green synthesized silver nanoparticles against uropathogen-Pseudomonas aeruginosa SU 18. Biocatal. Agric. Biotechnol. 2018, 16, 253-270, https://doi.org/10.1016/j.bcab.2018.08.014.

5. Samrot, A.V.; Shobana, N.; Jenna, R. Antibacterial and antioxidant activity of different staged ripened fruit of Capsicum annuum and its green synthesized silver nanoparticles. BioNanoScience 2018, 8, 632-646, https://doi.org/10.1007/s12668-018-0521-8.

6. Abbas, Q.M.S.; Phull, A.R.; Rafiq, M.; Hassan, M.; Lee, K.H.; Seo, S.Y. Green synthesis of silver nanoparticles using Bidens frondosa extract and their tyrosinase activity. Iran J Pharm Res 2017, 16, https://dx.doi.org/10.22037/ijpr.2017.2027.

7. Mukherjee, P.; Ahmad, A.; Mandal, D.; Senapati, S.; Sainkar, S.R.; Khan, M.I.; Parishcha, R.; Ajaykumar, P.V.; Alam, M.; Kumar, R.; Sastry, M. Fungus-mediated synthesis of silver nanoparticles and their immobilization in the mycelial matrix: a novel biological approach to nanoparticle synthesis. Nano Lett 2001, 1, 515-519, https://doi.org/10.1021/n10155274.

8. Barabadi, H.; Alizadeh, Z.; Rahimi, M.T.; Barac, A.; Maraolo, A.E.; Robertson, L.J.; Masjedi, A.; Shahrivar, F.; Ahmadpour, E. Nanobiotechnology as an emerging approach to combat malaria: a systematic review. Nanomed-Nanotechnol 2019,18, 221-233, https://doi.org/10.1016/j.nano.2019.02.017.

9. Barabadi, H.; Honary, S. Biofabrication of gold and silver nanoparticles for pharmaceutical applications. Pharm. Biomed. Res 2016, 2, 1-7, https://doi.org/10.18869/acadpub.pbr.2.1.1.

10. Barabadi, H.; Kobarfard, F.; Vahidi, H. Biosynthesis and characterization of biogenic tellurium nanoparticles by using Penicillium chrysogenum PTCC 5031: A novel approach in gold biotechnology. Iran J Pharm Res 2018, 17, 87.

11. Sperling, R.A.; Gil, P.R.; Zhang, F.; Zanella, M.; Parak, W.J. Biological applications of gold nanoparticles. Chem. Soc. Rev. 2008, 37, 1896-1908, https://doi.org/10.1039/B712170A.

12. Hirsch, L.R.; Stafford, R.J.; Bankson, J.A.; Sershen, S.R.; Rivera, B.; Price, R.E.; Hazle, J.D.; Halas, N.J.; West, J.L. Nanoshell-mediated near-infrared thermal therapy of tumors under magnetic resonance guidance. PNAS 2003, 100, 13549-13554, https://doi.org/10.1073/pnas.2232479100.

13. Tsai, C.Y.; Shiau, A.L.; Chen, S.Y.; Chen, Y.H.; Cheng, P.C.; Chang, M.Y.; Chen, D.H.; Chou, C.H.; Wang, C.R.; Wu, C.L. Amelioration of collagen-induced arthritis in rats by nanogold. Arthritis Rheum-US 2007, 56, 544-554, https://doi.org/10.1002/art.22401.

14. Samrot, A.V.; Bhavya, K.S.; Sahithya, C.S.; Sowmya, N. Evaluation of toxicity of chemically synthesised gold nanoparticles against Eudrilus eugeniae. J Clust Sci 2018, 29, 1217-1225, https://doi.org/10.1007/s10876-018-1440-0.

15. Barabadi, H.; Ovais, M.; Shinwari, Z.K.; Saravanan, M. Anti-cancer green bionanomaterials: present status and future prospects. Green Chem Lett Rev 2017, 10, 285-314, https://doi.org/10.1080/17518253.2017.1385856. 
16. Barabadi, H.; Tajani, B.; Moradi, M.; Kamali, K.D.; Meena, R.; Honary, S.; Mahjoub, M.A.; Saravanan, M. Penicillium family as emerging nanofactory for biosynthesis of green nanomaterials: a journey into the world of microorganisms. J Clust Sci 2019, 30, 843-856, https://doi.org/10.1007/s10876-019-01554-3.

17. Kalimuthu, K.; Babu, R.S.; Venkataraman, D.; Bilal, M.; Gurunathan, S. Biosynthesis of silver nanocrystals by Bacillus licheniformis. Colloid Surface $B \quad \mathbf{2 0 0 8 ,}$ 65, 150-153, https://doi.org/10.1016/j.colsurfb.2008.02.018.

18. Parida, U.K.; Bindhani, B.K.; Nayak, P. Green synthesis and characterization of gold nanoparticles using onion (Allium cepa) extract. World Journal of Nano Science and Engineering 2011, 1, 93-98, http://dx.doi.org/10.4236/wjnse.2011.14015.

19. Khatua, A.; Priyadarshini, E.; Rajamani, P.; Patel, A.; Kumar, J.; Naik, A.; Saravanan, M.; Barabadi, H.; Prasad, A.; Paul, B.; Meena, R. Phytosynthesis, characterization and fungicidal potential of emerging gold nanoparticles using Pongamia pinnata leave extract: a novel approach in nanoparticle synthesis. J Clust Sci 2020, 31, 125-131, https://doi.org/10.1007/s10876-019-01624-6.

20. Rahimi, M.T.; Ahmadpour, E.; Esboei, B.R.; Spotin, A.; Koshki, M.H.K.; Alizadeh, A.; Honary, S.; Barabadi, H.; Mohammadi, M.A. Scolicidal activity of biosynthesized silver nanoparticles against Echinococcus granulosus protoscolices. Int J Surg 2015, 19, 128-133, https://doi.org/10.1016/j.ijsu.2015.05.043.

21. Ankamwar, B. Biosynthesis of gold nanoparticles (green-gold) using leaf extract of Terminalia catappa. $E$ J Chem 2010, 7, https://doi.org/10.1155/2010/745120.

22. Nune, S.K.; Chanda, N.; Shukla, R.; Katti, K.; Kulkarni, R.R.; Thilakavathy, S.; Mekapothula, S.; Kannan, R.; Katti, K.V. Green nanotechnology from tea: phytochemicals in tea as building blocks for production of biocompatible gold nanoparticles. J. Mater. Chem. 2009, 19, 2912-2920, https://doi.org/10.1039/B822015H.

23. Chyou, C.C.; Tsai, S.Y.; Ko, P.T.; Mau, J.L. Terminalia catappa Linn.(Combretaceae). Food Chem. 2002, 78, 483-488

24. Lee, K.X.; Shameli, K.; Yew, Y.P.; Teow, S.Y.; Jahangirian, H.; Rafiee-Moghaddam, R.; Webster, T.J.Recent Developments in the Facile Bio-Synthesis of Gold Nanoparticles (AuNPs) and Their Biomedical Applications. International journal of nanomedicine $\mathbf{2 0 2 0}, \quad$ 15, 275-300, https://doi.org/10.2147/IJN.S233789.

25. Keijok, W.J.; Pereira,R.H.A.; Alvarez, L.A.C. Controlled biosynthesis of gold nanoparticles with Coffea arabica using factorial design. Sci Rep 2019, 9, 16019, https://doi.org/10.1038/s41598-019-52496-9.

26. Islam, N.U.; Jalil, K.; Shahid, M.; Rauf, A.; Muhammad, N.; Khan, A.; Shah, M.R.; Khan, M.A. Green synthesis and biological activities of gold nanoparticles functionalized with Salix alba, Arabian Journal of Chemistry 2019, http://dx.doi.org/10.1016/j.arabjc.2015.06.025.

27. Wang ,L.; Xu, J.; Yan, Y.; Liu, H.; Karunakaran, T.; Li, F. Green synthesis of gold nanoparticles from Scutellaria barbata and its anticancer activity in pancreatic cancer cell (PANC-1), Artificial Cells, Nanomedicine, and Biotechnology 2019, 47, 1617-1627, https://doi.org/10.1080/21691401.2019.1594862.

28. Wongyai, K.; Wintachai, P.; Maungchang, R.; Rattanakit, P. Exploration of the antimicrobial and catalytic properties of gold nanoparticles greenly synthesized by Cryptolepsis buchanani Roem and schult extract,Journal of Nanomaterials 2020, 11, 1320274, https://doi.org/10.1155/2020/1320274.

29. Barabadi, H.; Alizadeh, A.; Ovais, M.; Ahmadi, A.; Shinwari, Z.K.; Saravanan, M. Efficacy of green nanoparticles against cancerous and normal cell lines: a systematic review and meta-analysis. Iet Nanobiotechnol 2017, 12, 377-391, https://doi.org/10.1049/iet-nbt.2017.0120.

30. Saravanan, M.; Asmalash, T.; Gebrekidan, A.; Gebreegziabiher, D.; Araya, T.; Hilekiros, H.; Barabadi, H.; Ramanathan, K. Nano-medicine as a newly emerging approach to combat human immunodeficiency virus (HIV). Pharm. Nanotechnol 2018, 6, 17-27, https://doi.org/10.2174/2211738506666180209095710.

31. Barabadi, H.; Alizadeh, Z.; Rahimi, M.T.; Barac, A.; Maraolo, A.E.; Robertson, L.J.; Masjedi, A.; Shahrivar, F.; Ahmadpour, E. Nanobiotechnology as an emerging approach to combat malaria: a systematic review. Nanomed-Nanotechnol 2019, 18, 221-233, https://doi.org/10.1016/j.nano.2019.02.017.

32. Mortezaee, K.; Najafi, M.; Samadian, H.; Barabadi, H.; Azarnezhad, A.; Ahmadi, A. Redox interactions and genotoxicity of metal-based nanoparticles: A comprehensive review. Chem. Biol. Interact. 2019, 312, https://doi.org/10.1016/j.cbi.2019.108814.

33. Honary, S.; Barabadi, H.; Gharaei-Fathabad, E.; Naghibi, F. Green synthesis of silver nanoparticles induced by the fungus Penicillium citrinum. Trop J Pharm Res 2013, 12, 7-11, https://doi.org/10.4314/tjpr.v12i1.2.

34. Barabadi, H.; Honary, S.; Ebrahimi, P.; Alizadeh, A.; Naghibi, F.; Saravanan, M. Optimization of mycosynthesized silver nanoparticles by response surface methodology employing Box-Behnken design. Inorg. Nano-Met. Chem. 2019, 49, 33-43, https://doi.org/10.1080/24701556.2019.1583251.

35. Honary, S.; Barabadi, H.; Ebrahimi, P.; Naghibi, F.; Alizadeh, A. Development and optimization of biometal nanoparticles by using mathematical methodology: A microbial approach. J Nano Res-Sw 2015, 30, 106115, https://doi.org/10.4028/www.scientific.net/JNanoR.30.106.

36. Vijayarekha, P.; Sangottaiyan, N.; Noorjahan, A.; Ambiga, S. Antibacterial activity of Acalypha indica Linn. J Curr Microbiol Appl Sci 2015, 4, 1133-1138. 
37. Jahangirian, H.; Haron, M.J.; Shah, M.H.; Abdollahi, Y.; Rezayi, M.; Vafaei, N. Well diffusion method for evaluation of antibacterial activity of copper phenyl fatty hydroxamate synthesized from canola and palm kernel oils. Dig J Nanomater Bios 2013, 8, 1263-1270.

38. Pal, S.; Tak, Y.K.; Song, J.M. Does the antibacterial activity of silver nanoparticles depend on the shape of the nanoparticle? A study of the gram-negative bacterium Escherichia coli. Appl. Environ. Microbiol. 2007, 73, 1712-1720, https://doi.org/10.1128/AEM.02218-06.

39. Maruthai, K.; Vallayyachari, K.; Ravibalan, T.; Philip, S.A.; Samrot, A.V.; Muthuraj, M. Antibacterial activity of the Silver Nanoparticles against Escherichia coli and Enterobacter sp. Progress in Bioscience and Bioengineering 2017, 1, 29-35, https://doi.org/10.29269/pbb2017.v1i1.1.

40. Gunalan, S.; Sivaraj, R.; Rajendran, V. Green synthesized ZnO nanoparticles against bacterial and fungal pathogens. Prog. Nat. Sci 2012, 22, 693-700, https://doi.org/10.1016/j.pnsc.2012.11.015.

41. Iravani, S. Green synthesis of metal nanoparticles using plants. Green Chem. 2011, 13, 2638-2650, https://doi.org/10.1039/C1GC15386B.

42. Li, S.; Shen, Y.; Xie, A.; Yu, X.; Qiu, L.; Zhang, L.; Zhang, Q. Green synthesis of silver nanoparticles using Capsicum annuum L. extract. Green Chem. 2007, 9, 852-858, https://doi.org/10.1039/B615357G.

43. Krishnaraj, C.; Muthukumaran, P.; Ramachandran, R.; Balakumaran, M.D. and Kalaichelvan, P.T. Acalypha indica Linn: biogenic synthesis of silver and gold nanoparticles and their cytotoxic effects against MDAMB-231, human breast cancer cells. Biotechnol Rep 2014, 4, 42-49, https://doi.org/10.1016/j.btre.2014.08.002.

44. Annamalai, A.; Babu, S.T.; Jose, N.A.; Sudha, D.; Lyza, C.V. Biosynthesis and characterization of silver and gold nanoparticles using aqueous leaf extraction of Phyllanthus amarus Schum \& Thonn. World Appl. Sci. J.2011, 13, 1833-1840.

45. Barabadi, H.; Honary, S.; Mohammadi, M.A.; Ahmadpour, E.; Rahimi, M.T.; Alizadeh, A.; Naghibi, F.; Saravanan, M. Green chemical synthesis of gold nanoparticles by using Penicillium aculeatum and their scolicidal activity against hydatid cyst protoscolices of Echinococcus granulosus. Environ. Sci. Pollut. Res. 2017, 24, 5800-5810, https://doi.org/10.1007/s11356-016-8291-8.

46. Ahmad, A.; Wei, Y.; Syed, F.; Imran, M.; Khan, Z.U.H.; Tahir, K.; Khan, A.U.; Raza, M.; Khan, Q.; Yuan, Q. Size dependent catalytic activities of green synthesized gold nanoparticles and electro-catalytic oxidation of catechol on gold nanoparticles modified electrode. RSC Adv. 2015, 5, 99364-99377, https://doi.org/10.1039/C5RA20096B.

47. Shankar, S.S.; Rai, A.; Ahmad, A.; Sastry, M. Rapid synthesis of Au, Ag, and bimetallic Au core-Ag shell nanoparticles using Neem (Azadirachtaindica) leaf broth. J. Colloid Interface Sci. 2004, 275, 496-502, https://doi.org/10.1016/j.jcis.2004.03.003.

48. Sahayaraj, K.; Rajesh, S.; Rathi, J.M. Silver Nanoparticles Biosynthesis Using Marine Alga Padina pavonica(Linn.) And Its Microbicidal Activity. Dig J Nanomater Bios 2012, 7, 1557-1567.

49. Barabadi, H.; Honary, S.; Ebrahimi, P.; Mohammadi, M.A.; Alizadeh, A.; Naghibi, F. Microbial mediated preparation, characterization and optimization of gold nanoparticles. Braz. J. Microbiol. 2014, 45, 14931501, https://doi.org/10.1590/S1517-83822014000400046.

50. Khatua, A.; Prasad, A.; Priyadarshini, E.; Patel, A.K.; Naik, A.; Saravanan, M.; Barabadi, H.; Paul, B.; Paulraj, R.; Meena, R. Emerging antineoplastic plant-based gold nanoparticle synthesis: a mechanistic exploration of their anticancer activity toward cervical cancer cells. J Clust Sci 2019, 2019, 1-12, https://doi.org/10.1007/s10876-019-01742-1.

51. Slavin, Y.N.; Asnis, J.; Häfeli, U.O.; Bach, H. Metal nanoparticles: understanding the mechanisms behind antibacterial activity. J. Nanobiotechnology 2017, 15, 1-20, https://doi.org/10.1186/s12951-017-0308-z.

52. Stensberg, M.C.; Wei, Q.; McLamore, E.S.; Porterfield, D.M.; Wei, A.; Sepúlveda, M.S. Toxicological studies on silver nanoparticles: challenges and opportunities in assessment, monitoring and imaging. Nanomedicine 2011, 6, 879-898, https://doi.org/10.2217/nnm.11.78.

53. Paul, B.; Bhuyan, B.; Purkayastha, D.D.; Dhar, S.S. Photocatalytic and antibacterial activities of gold and silver nanoparticles synthesized using biomass of Parkiaroxburghii leaf. J Photoch Photobio B 2016, 154, 1-7, https://doi.org/10.1016/j.jphotobiol.2015.11.004.

54. Raji, P.; Samrot, A.V.; Keerthana, D.; Karishma, S. Antibacterial Activity of Alkaloids, Flavonoids, Saponins and Tannins Mediated Green Synthesised Silver Nanoparticles Against Pseudomonas aeruginosa and Bacillus subtilis. J Clust Sci 2019, 30, 881-895, https://doi.org/10.1007/s10876-019-01547-2.

55. Samrot, A.S.; Silky, V.I.C.; Raji, P.; SaiPriya, C. and Selvarani, J.A. Bioactivity Studies of Datura metel, Aegle marmelos, Annona reficulata and Saraca indica and their Green Synthesized Silver Nanoparticle. $J$ Pure Appl Microbiol 2019, 13, 329-338, https://dx.doi.org/10.22207/JPAM.13.1.36.

56. Barabadi, H.; Najafi, M.; Samadian, H.; Azarnezhad, A.; Vahidi, H.; Mahjoub, M.A.; Koohiyan, M.; Ahmadi, A. A systematic review of the genotoxicity and antigenotoxicity of biologically synthesized metallic nanomaterials: are green nanoparticles safe enough for clinical marketing? Medicina 2019, 55, https://doi.org/10.3390/medicina55080439. 